\title{
Global Regularities Of The Development Of The World Market Of Aviation Transportation
}

\author{
OLENA LOZHACHEVSKA, \\ KATERYNA SYDORENKO, \\ SVITLANA SidenKo ${ }^{1}$
}

\begin{abstract}
The Article is devoted to the substantiation of the key global regularities of the development of the world market of aviation transportation on the basis of a comprehensive generalization of the stages of society's development in the context of infrastructure transformations, the identification of trends and structural dominants of the global air transport services market. The study uses a systematic approach, the methodological basis of work includes the position of theories and concepts of development of society, conceptual approaches to the study of the world market of services, in particular the world market of air transportation services. The source and statistical basis of the Article are monographic studies and periodical publications of domestic and foreign economists-scientists, materials and analytical reports of the World Bank, the European Commission, the World Trade Organization, aggregated data of the International Civil Aviation Organization, the International Air Transport Association, the International Council of Airports, the open information Internet resources. The work systematized the socio-technological and infrastructural parameters of forming the stages of society's development. It has been established that during each phase (from agrarian to knowledge economics and network society) the infrastructure has undergone revolutionary transformational changes caused by technological innovations, as well as due to the shift in the structure of production, and in the present conditions, becomes a global character, forming a global communications network. It has been researched critically the structural changes in the world market of services and found that in the post-industrial society, the sphere of material production does not lose importance, but the modern stage of the formation of human civilization is characterized by accelerated development and diversification of the sphere of services practically all over the world - a decrease in the share of raw materials and agriculture, capital-intensive industries, rapid growth of service sector, due to increased physical volumes of trade in the global economy, development in transport, tourism and other services. It has been established that the
\end{abstract}

\footnotetext{
* This article was translated from its original in Ukrainian

${ }^{1}$ Olena Lozhachevska - Doctor of Science, Economics, Professor, Head of the Department of Management of NTU. She is the author of more than 130 scientific and methodological works, including monographs, scientific guides (co-authored) published in Ukraine and in foreign publications. Sphere of scientific interests: development of methods for optimal functioning and management of strategic development of the transport complex and its infrastructure, modern problems of global processes in the world economy, international management, research of processes of integration interaction of economic entities and prospects of their economic development in the conditions of globalization. E-mail: lemina@ukr.net

Kateryna Sydorenko is a Senior Lector at the Department of Economics of Air Transport of the National Aviation University. In 2018 she defended a dissertation for the degree of a Candidate of economic sciences. She is the author of more than 60 scientific and methodological works published in Ukraine and in foreign publications. Sphere of scientific interests: international economic relations in the aviation sector, formation of global industrial infrastructure, management of the competitiveness of international airports, integration processes in aviation. Email: sidorkate@gmail.com

Svitlana Sidenko - Doctor of Science, Economics, Professor, Head of the Department of International Economic Relations and Business of the Institute of International Relations, National Aviation University. She is the author of more than 160 scientific and methodological works, including two monographs and sections in 18 collective monographs, scientific guides (co-authored) published in Ukraine and abroad. Sphere of scientific interests: problems of globalization of economy, European integration, competitiveness of economy, innovation development, market models, social development. E-mail: sv sidenko@ukr.net
}

IEP, № 29, (2018) pp. 50-70

(C) Olena Lozhachevska, Kateryna Sydorenko, Svitlana Sidenko, 2018 «All rights reserved» ISSN 1811-9832/2018/№ 2 (29) 
characteristic feature of post-industrialism is the increase of volumes of services of international air passenger and freight transportation, their regional diversification and strengthening of interdependence of national economies, since improving air transport infrastructure and reducing transportation costs under the influence of scientific and technological progress allows intensification of trade and economic cooperation between geographically distant regions, leads to a reduction in the cost of spatial organization of international economic systems, creates the preconditions for strengthening integration processes. The results of the work can be used in further scientific studies and practical developments in the field of detection and substantiation of global regularities of development of the world market of aviation transportation, increase of productivity of national economies, increase of the level of social and economic welfare of the population.

KEYWORDS. Postindustrial society, networking, infrastructure, service market, tertiary sector, air transportation, air transport.

\section{Introduction}

In today's conditions of dynamic development of the world economy and international economic relations the role of international air transportation is significantly increased as, being one of the main system-forming elements of the global networking of society, the functioning of the world air transport market creates the preconditions for strengthening the integration processes by ensuring the free movement of passengers and cargo, involving countries to participate in international trade and is one of the fundamental factors of socioeconomic growth of national economies both in the short-term and in the long-term prospects.

The basic provisions of the development of transport infrastructure have been reflected in numerous studies of such foreign and Ukrainian scientists as M. Butko ${ }^{2}$ V. Heiets ${ }^{3}$, N. Ivanova ${ }^{4}$ D. Cunning ${ }^{5}$, N. Krafts $^{6}$, V. Kuryliak ${ }^{7}$, V. Novytskyi ${ }^{8}$, B. Piriashvili' ${ }^{9}$, P. Ritveld ${ }^{10}$, A.

\footnotetext{
${ }^{2}$ Butko M.P., Sydorenko I.V. (2013) Evoliutsiini pohliady na modernizatsiiu riznykh iierarkhichnykh rivniv vyrobnychoi infrastruktury. Ekonomist, 3, s. 11-14 [In Ukranian].

${ }^{3}$ Heiets V.M. (2014) Modernizatsiia v systemi «suspilstvo - derzhava - ekonomika». Zhurnal yevropeiskoi ekonomiky, 13, 3, s. 221-235 [In Ukranian].

Ivanova N.V. (2015) Metodolohichni aspekty formuvannia peredumov modernizatsii vyrobnychoi infrastruktury. Hlobalni ta natsionalni problemy ekonomiky, 6, s. 543-549 [In Ukranian].

5 Canning D., Pedroni P. (2004) The effect of infrastructure on long run economic growth. M.: Harvard University.

${ }^{6}$ Crafts N. (2009) Transport infrastructure investment: implications for growth and productivity. Oxford review of economic policy, 25 (3), p. 27-43. DOI: 10.1093/oxrep/grp021

Saveliev Ye., Kuryliak V. (2018) Ukraina v hlobalnykh protsesakh posylennia intehratsii elektrychnoho transportu v systemu hromadskykh perevezen. Zhurnal yevropeiskoi ekonomiky, 17, 1, s. 98-109 [In Ukranian].

${ }^{8}$ Novytskyi V.Ie. (2003) Mizhnarodna ekonomichna diialnist Ukrainy. K.: KNEU [In Ukranian].

${ }^{9}$ Piriashvili B.Z., Chyrkin B.P., Nykyforuk O.I. ta in. (2014) Zasady modernizatsii vyrobnychoi infrastruktury Ukrainy. K.: In-t ekon. ta prohnozuv. NAN Ukrainy [In Ukranian].

Rietveld P., Nijkamp P. (1993) Transport and regional development. European transport economics. Paris: RCMT, p. 130-151.
} 
Rybchuk $^{11}$, Ye. Saveliev ${ }^{12}$, A. Khakhliuk ${ }^{13}$, O. Shevtsova ${ }^{14}$, S. Yurchenko $^{15}$ and others. The theoretical and applied questions of solving multifaceted problems of functioning and development of the world market of aviation transportation are devoted to the work of such modern Economists as K. Button ${ }^{16}$, P. Belobaba ${ }^{17}$, M. Hryhorak ${ }^{18}$, M. Hrychkoiedov $^{19}$, N. Itani ${ }^{20}$, M. Crockett ${ }^{21}$, P. Makario ${ }^{22}$, K. Marintsev ${ }^{23}$, A. Odoni ${ }^{24}$, O. Polous ${ }^{25}$, O. Poltoratska ${ }^{26}$, J. O'Connell ${ }^{27}$, V. Chuzhykov $^{28}$, D. Henscher ${ }^{29}$, M. Hussein ${ }^{30}$.

Meanwhile, despite the existence of deep and thorough scientific developments of scientists of different years, the problems of separation and substantiation of global regularities of the development of the world market of aviation transportation are not sufficiently worked out by economic science. The characteristics of socio-technological and infrastructural parameters of the formation of the phases of development of society, specialization of structural changes in the world market of

\footnotetext{
${ }^{11}$ Rybchuk A.V. (2010) Formuvannia hlobalnoi vyrobnychoi infrastruktury svitovoho hospodarstva: avtoref. dys... d-ra ekon. nauk spets. 08.00.02. K.: Kyivskyi natsionalnyi universytet imeni Tarasa Shevchenka [In Ukranian].

${ }_{12}$ Saveliev Ye., Kuryliak V. (2018) Ukraina v hlobalnykh protsesakh posylennia intehratsii elektrychnoho transportu v systemu hromadskykh perevezen. Zhurnal yevropeiskoi ekonomiky, 17, 1, s. 98-109 [In Ukranian].

3 Khakhliuk A.M. (2007) Infrastrukturni haluzi u svitovomu hospodarstvi. U: A.S.Filipenko (red.) Svitova ekonomika. K.: Lybid, s. 314-334 [In Ukranian].

Shevtsova O.I. (2001) Orhanizatsiino-ekonomichnyi mekhanizm upravlinnia promyslovoiu infrastrukturoiu subiektiv hospodariuvannia: avtoref. dys. ... d-ra ekon. nauk spets. 08.06.01. Donetsk: Instytut ekonomiky promyslovosti NAN Ukrainy [In Ukranian].

${ }_{16}^{15}$ Yurchenko S.A. (2006) Infrastruktura mira. Kh.: KhNU [In Russian].

16 Button K., Vega H. (2012) Globalization and transport (The globalization of the world economy series. Cheltenham: Edward Elgar Pub.

${ }_{18}^{17}$ Belobaba P., Odoni A., Barnhart C. (2009) The Global Airline Industry. West Sussex: Wiley. Ukranian].

Hryhorak M.Iu., Savchenko L.V. (2017) Lohistychni kontseptsii rozvytku aeroportiv. K.: Lohos [In

${ }^{19}$ Hrychkoiedova M.V. (2010) Suchasni tendentsii rozvytku biznes-aviatsii u sviti. Problemy pidvyshchennia efektyvnosti infrastruktury, 28, s. 247 [In Ukranian]

${ }^{20}$ Itani N., O'Connell J., Mason K. (2014) A macro-environment approach to civil aviation strategic planning. Transport Policy, 33, p. 125-135. DOI: 10.1016/j.tranpol.2014.02.024

${ }^{21}$ Crockat M. (2000) Airport infrastructure and regional development: a case for resurrecting the growth pole concept. Winnipeg: University of Manitoba.

${ }^{22}$ Macario R., Voorde E. (2010) Critical issues in air transport economics and business. N.Y.: Routledge.

23 Marintseva K. (2013) Analysis of air transport network of Ukraine. Управління проектами, системний аналіз і логістика, 12, с. 97-109.

${ }_{25}^{24}$ Belobaba P., Odoni A., Barnhart C. (2009) The Global Airline Industry. West Sussex: Wiley.

25 Polous O.V. (2018) Osoblyvosti funktsionuvannia lohistychnykh system na meha-, makro- ta makrorivni. Ekonomika. Finansy. Pravo, 1/3, s. 20-24 [In Ukranian].

${ }^{26}$ Poltoratska O.T. (2012) Koordynatsiia ta vdoskonalennia vzaiemovidnosyn mizh subiektamy aviatsiinoho prostoru. Stratehiia rozvytku Ukrainy, 3, s. 201-207 [In Ukranian].

${ }^{27}$ Itani N., O’Connell J., Mason K. (2014) A macro-environment approach to civil aviation strategic planning. Transport Policy, 33, p. 125-135. DOI: 10.1016/j.tranpol.2014.02.024

${ }^{28}$ Chuzhykov V.I. (2010) Aviatsiini aliansy v hlobalnii konkurentnii modeli KhKhI stolittia. Visnyk Derzhavnoi komisii z tsinnykh paperiv ta fondovoho rynku, 3-4, s. 9-16 [In Ukranian].

${ }^{29}$ Hensher D. (2010) Transport Economics and Markets. Economic Papers: A journal of applied economics and policy, 20, 2. DOI: 10.1111/j.1759-3441.2001.tb00280.x.

${ }^{30}$ Hussain M. (2010) Investment in Air Transport Infrastructure. Washington: World Bank.
} 
services, identification of global trends in the formation of the world market for aviation transport need further study.

The purpose of the Article is to substantiate the key global regularities of the development of the world market of aviation transportation on the basis of an integrated generalization of the stages of society development in the context of infrastructure transformational changes, the identification of trends and structural domains of the global air transport market.

\section{Stages of society development in terms of causal socio- technological and infrastructural transformational changes}

For a good understanding of the fundamental trends and global regularities of the development of the world market of aviation transportation, it is necessary to address the theories of post-industrial society, which in some way explain the impact of industrialization, modernization, development of the service sector on the socio-economic growth of national economies, increase their competitiveness in the global economy, and allow more clearly understand the global architecture of world economic relations. Concepts of the post-industrial society have received extensive coverage in the works of many prominent scientists: D. Bell ${ }^{31}$, J. Galbraith ${ }^{32}$, M. Castells ${ }^{33}$, J. Masudi $^{34}$, M. Porata ${ }^{35}$, T. Stounier ${ }^{36}$, E. Toffler ${ }^{37}$ and others. A significant contribution to the development of the basic provisions of the economic component of the theory of post-industrialism belongs to such Ukrainian scientists as O. S. Burmich ${ }^{38}$, A. S. Halchynskyi ${ }^{39}$, V. M. Heiets ${ }^{40}$, V.V. Zinchenko ${ }^{41}$, O. D. Lukianenko ${ }^{42}, \mathrm{Yu} \mathrm{V}$. Orlovska ${ }^{43}$,

\footnotetext{
${ }_{32}^{31}$ Bell D. (1973) The coming of postindustrial society: A venture of social forecasting. N.Y.: Basic Books.

${ }^{32}$ Gelbreyt Dzh. K. (1969) Novoe industrialnoe obshchestvo. Per. s angl. M.: Progress [In Russian].

${ }^{33}$ Castells M. (2000) The Information Age: Economy Society and Culture. Volume I: The Rise of the Network Society. Second Edition. Oxford: Blackwel.

${ }_{34}$ Masuda Y. (1981) The information society as post-industrial society. Washington, D.C.: World Future Society.

${ }^{35}$ Porat M., Rubin M. (1978) The Information Economy: Development and Measurement. Washington: Scientific Review.

${ }^{36}$ Stonier T. (1983) The Wealth of Information. London: Oxford University Press.

37 Toffler A. (1980) The Third Wave. New York: Bantam

${ }^{38}$ Burmich O.S., Lukianenko O.D., Panchenko Ye.H., Chuzhykov V.I. (2013) Tekhnolohichna modernizatsiia v Yevropeiskii ekonomitsi. K.:KNEU [In Ukranian].

Halchynskyi A.S., Heiets V.M., Kinakh A.K., Semynozhenko V.P. (2004) Innovatsiina stratehiia ukrainskykh reform. K.: Znannia Ukrainy [In Ukranian].

${ }^{40}$ Ibid.

${ }^{41}$ Zinchenko V.V. (2013) Postindustrializm, dynamika protsesiv samoorhanizatsii i upravlinska demokratiia v perspektyvakh transformatsiinykh zmin vektoriv hlobalnoho rozvytku. Hileia: naukovyi visnyk, 70, s. 337-348 [In Ukranian].

${ }^{42}$ Burmich O.S., Lukianenko O.D., Panchenko Ye.H., Chuzhykov V.I. (2013) Tekhnolohichna modernizatsiia v Yevropeiskii ekonomitsi. K.:KNEU [In Ukranian].

${ }_{43}$ Orlovska Yu.V., Chala V.S. (2013) Vplyv hlobalnykh problem rozvytku postindustrialnoi ekonomiky na kreatyvizatsiiu zovnishnoekonomichnoi diialnosti pidpryiemstv. Ekonomichnyi prostir, 78, s. 32-44 [In Ukranian].
} 
Ye. H. Panchenko ${ }^{44}$, Yu. Pakhomov ${ }^{45}$, A. S. Filipenko ${ }^{46}$, V. I. Chuzhykov $^{47}$, A. Chukhno ${ }^{48}$ and others.

Thus, in 1960 the American Economist Walt Rostow ${ }^{49}$ proposed five historical stages of society's development: a traditional society, prerequisites for economic growth, rise, movement towards maturity, the era of mass consumption. The scientist expressed the position that transformational transitions between stages are justified by technological innovations, the speed of economic growth, changes in the structure of production.

The basic methodological principles of the theory of post-industrial society have evolved in the 1970's in the writings of Daniel Bell ${ }^{50}$, a Professor at Harvard University (USA). Studying the three-sectoral structure of the Economics (proposed in the 1930s by New Zealand Economist A. Fischer ${ }^{51}$ and British Economist K. Clarke ${ }^{52}$ ), which distinguishes the «primary sector» - agriculture and extractive industries, the «secondary sector» - the manufacturing industries and construction, «tertiary sector» - the field of services, the scientist complemented by two stages: «quaternary» and «fifth», which reflect the transition from industrial to postindustrial societies. According to this model of services, the «tertiary sector» includes transport and utilities, to «quaternary» - trade, insurance, real estate operations and financial services, and to the «fifth sector» - health, education, research, rest and public administrations.

D. Bell distinguishes the stages of the formation of a global economy on the following criteria: «for the predominant resources, the method of production activity, the organization of technology and the nature of the construction of human relations and nature. ${ }^{53}$ "Whereas, industrial society is characterized by the number of goods that indicate a standard of living and postindustrial society is characterized by a standard of quality of life and measured by services - health care, recreation and cultural leisure.

\footnotetext{
${ }^{44}$ Burmich O.S., Lukianenko O.D., Panchenko Ye.H., Chuzhykov V.I. (2013) Tekhnolohichna modernizatsiia v Yevropeiskii ekonomitsi. K.:KNEU [In Ukranian].

Pakhomov Yu.N. Cmena tsely razvytyia kak sposob predotvrashchenyia katastrofы v postyndustryalnom obshchestve. Ekonomichnyi Chasopys - XXI, 1-2, s. 3-4 [In Ukranian].

${ }_{46}$ Filipenko A.S. (2016) Ekonomichnyi svit: epistemolohiia. Ekonomichna teoriia, 1, s. 17-25 [In Ukranian].

${ }^{47}$ Burmich O.S., Lukianenko O.D., Panchenko Ye.H., Chuzhykov V.I. (2013) Tekhnolohichna modernizatsiia v Yevropeiskii ekonomitsi. K.:KNEU [In Ukranian].

${ }^{48}$ Chukhno A.A. (2003) Postindustrialna ekonomika: teoriia, praktyka ta yikh znachennia dlia Ukrainy. K.: Lohos [In Ukranian].

49 Rostow W. (1960) The stages of economic growth. 3rd ed. N.Y.: Cambridge University Press. DOI: 10.1017/CBO9780511625824.

${ }_{50}^{50}$ Bell D. (1973) The coming of postindustrial society: A venture of social forecasting. N.Y.: Basic Books.

51 Fisher A. (1939) Production, primary, secondary and tertiary. Economic Record, 15.1, pp. 24-38. DOI: 10.1111/j.1475-4932.1939.tb01015.x

${ }^{52}$ Clark C. (1940) The Conditions of Economic Progress. London: Macmillan.

${ }^{53}$ Bell D. (1976) The Cultural Contradictions of Capitalism. NY.: Basic Books.
} 
The features of the post-industrial stage of society's development are as follows: in the field of Economics - the shift from manufacture of goods to the production of services; in the sphere of Employment - the predominance of employees of mental labor; in the field of Science - the leading role of theoretical knowledge as a source of innovation; in the sphere of Management - decision-making on the basis of means of new intellectual technologies; in the field of Ecology - control over the technique and assessment of the possible consequences of technical innovations. Consequently, unlike the industrial society that was organized around the coordination of machines and human labor for the production of goods, post-industrial society was «organized around knowledge for the purpose of social control and the orientation of innovation and change» ${ }^{54}$.

Within the theory of post-industrialism it is expedient to distinguish E. Toffler's concept ${ }^{55}$ of «three waves of society development», according to which the first wave of the history of civilization is agrarian (until the XVIII ${ }^{\text {th }}$ century), the second is industrial (until the 1950s), the third is post-or super industrial (since the 1950s of the $\mathrm{XX}^{\text {th }}$ century). Investigating the centuries-long history of mankind through the prism of globally synchronous phases, the scientist focuses on the technical and economic and information and communication factors of social development.

A characteristic feature of the first wave is a simple division of labor and small number of clearly distinguished classes of society. Industrialization, introduction of new technologies, innovations in the energy sector caused the second wave of society; according to E. Toffler $^{56}$, the third wave differs radical changes (the use of renewable energy sources, non-standardized production, the emergence of radically new schools, etc.), based on significant achievements in science and the implementation of information and communication technologies. Thus, it has been determined the growing role of information and knowledge in the production process for the main feature of post-industrial society ${ }^{57}$.

The theory of the information society was extended by such scientists as R.Katz ${ }^{58}$, J.Masuda ${ }^{59}$, M.Porat ${ }^{60}$, T.Stounier ${ }^{61}$. Thus, while

\footnotetext{
${ }^{54}$ Bell D. (2004) Gryadushchee postindustrialnoe obshchestvo. Opyt sotsialnogo prognozirovaniya. Perevod s angl. V. Inozemtsev. M.: Academia [In Russian].

${ }_{55}$ Toffler A. (1980) The Third Wave. New York: Bantam.

${ }_{57}^{56}$ Ibid.

${ }^{57}$ Sidenko S.V. (2014) Problemy innovatsiinoho rozvytku v umovakh hlobalizatsii. Stratehiia rozvytku Ukrainy (ekonomika, sotsiolohiia, pravo), 2 [In Ukranian].

Sidenko S.V. (2016) Mizhnarodne spivrobitnytstvo Ukrainy v sferi innovatsii. Stratehiia rozvytku Ukrainy (ekonomika, sotsiolohiia, pravo), 1, c. 172-176 [In Ukranian].

${ }_{59}^{58}$ Katz R. (1988) The Information Society: An International Perspective. N.Y.: Praeger. Lindberg. Society.

9 Masuda Y. (1981) The information society as post-industrial society. Washington, D.C.: World Future
} 
investigating the socioeconomic aspect of the information society, $\mathrm{T}$. Stounier ${ }^{62}$ noted that the post-industrial economics is an economics in which industry in terms of employment and share in the national product is inferior to the service sector, and also emphasized that the processing and production of information contributes to the dissemination of knowledge and scientific discoveries.

Continuing to study the theory of post-industrial society, a number of scientists (P. Drucker ${ }^{63}$, N. Stern ${ }^{64}$, T. Sakaya ${ }^{65}$ and others) emphasize that the socioeconomic development of developed industrialized countries has provided an information society in which the main driving forces were information and communication technologies, as well as the growth of knowledge-based services. Within the framework of this concept, knowledge is considered as the main factor of production, and the preconditions for transition to a new Economics (knowledge economy) are market liberalization, acceleration of capital mobility, globalization of the market, the emergence of a digital environment as a general communications network.

The theory of the knowledge society is most fully substantiated by $\mathrm{N}$. Shter ${ }^{66}$. According to the scientist, the emergence of a knowledge society is not a revolutionary, but an evolutionary process in which the socioeconomic and cultural characteristics of society are gradually undergoing transformations. The main change in the knowledge economy is the domination of the intangible sphere over the material, since the cost of modern companies is more determined by their intangible assets and employee knowledge.

The World Bank ${ }^{67}$ has developed a special methodology for measuring the level of proximity of countries to knowledge economy in the Knowledge for Development program. The methodology is based on four elements: the regime of economic stimulation, education and competencies, information and communication infrastructure, an innovation system. According to the indicators, countries are assessed on the path to transition to a knowledge economy, as well as comparisons between countries.

Researching the various theories of post-industrial society, it has been established that the concepts of post-industrial society have influenced

\footnotetext{
${ }^{60}$ Porat M., Rubin M. (1978) The Information Economy: Development and Measurement. Washington: Scientific Review

${ }^{61}$ Stonier T. (1983) The Wealth of Information. London: Oxford University Press

${ }^{62}$ Ibid.

${ }_{64}^{63}$ Druker P. (1990) Postkapitalisticheskoe obshchestvo. M.: Academia [In Russian].

${ }^{64}$ Stehr N. (1994) Knowledge Societes. London: Sage

${ }^{65}$ Sakayya T. (1999) Stoimost, sozdavaemaya znaniyami ili Istoriya budushchego. M.: Academia [In Russian].

${ }_{67}^{66}$ Stehr N. (1994) Knowledge Societes. London: Sagev

${ }_{67}$ World Bank (2008) Knowledge for development. [online] Available at: http://www.worldbank.org/en/ publication/wdr/wdr-archive
} 
the formation of a new paradigm in the functioning of infrastructure, in particular in the global transport system ${ }^{68}$. In the information society, the socio-technological principle emphasizes the information economy with its regional agglomerations and metropolises. The principle of physical transportation is increasingly concentrated on the flow of bits in cables, but the principles of physical transportation of previous stages are also intensified. The volume of transportation by road, rail and sea transport is growing, however, in conditions where the transport system becomes more globalized and interconnected; air transportation is of great importance.

Information and communication technologies have contributed to the development of a sophisticated technological system in aviation, in particular in such areas as information service of aircraft passengers, cargo tracking system, air traffic management, navigation, autonomous systems of vehicles, etc ${ }^{69}$. According to the European Commission ${ }^{70}$, the intelligent transportation system and maintenance (transport telematics) will have enormous potential in the future and new types of services for the population will be introduced gradually. Implementation of the latest information and communication technologies will provide the necessary information about service and infrastructure needs, will help to increase transport safety and environmental sustainability.

The information society emphasizes the combination of electronic and physical transport, in today's world economy, the interweaving and continuous communication of transport and information infrastructure provides for the accumulation, processing and transportation of information / passengers / cargo, and is also a key factor in meeting the needs of users of infrastructure services ${ }^{71}$. Information and communication infrastructure becomes a public product and a service platform for industrial infrastructure ${ }^{72}$.

In the conditions of the dynamism of the World Economics, transport and communication technologies (railways, maritime, automobile, aviation, broadcast, digital, computer and communication technologies, the latest digital network technologies, etc.) accelerated the movement of global flows of capital, goods, energy, ideologies, and

\footnotetext{
${ }^{68}$ Lozhachevska O.M., Sydorenko K.V. (2017) Mistse vyrobnychoi infrastruktury mizhnarodnykh aeroportiv u systemi zabezpechennia hlobalnoi konkurentospromozhnosti. Ekonomichnyi prostir, 125, s. 17-26 [In Ukranian].

Sidenko S. (2016) Innovation priorities of Ukraine: the aerospace sector. Economics\&Education International Scientific Journal, №2, p. 14-18.

European Commission (2016b) The implementation of the 2011 White Paper on Transport «Roadmap to a Single European Transport Area — towards a competitive and resource-efficient transport system» five years after its publication: achievements and challenges. Brussels: European Commission

Balbi G., Moraglio M. (2016) A Proposal to hybridise communication and mobility research agendas. In: S. Fari, M. Moraglio, eds. Peripheral flows: A Historical Perspective on Mobilities between Cores and Fringes. Newcastle: Cambridge Scholars Publishing, p. 10-27. Ukranian].
} 
communications and information. Earth is increasingly turning into a global communications network that affects all spheres of society's life, as evidenced by the study of supporters of the network society ${ }^{73}$.

The theory of network society is a neo-liberally restructured version of the «information society», which is associated with increased flexibility, individuality and a new culture of innovation. According to M. Castells ${ }^{74}$, industrialism has been replaced by informationism, and this is a new economic paradigm that focuses on «knowledge generation, information processing and symbolic communication,» and all this is achieved through cutting-edge information and communication technologies. The scientist argues that the Economics of the late $\mathrm{XX}^{\text {th }}$ century is information in content, because the productivity and competitiveness of economic agents is fundamentally dependent on the ability to generate, process, and effectively use knowledge-based information. Economics «is global because the main activities, such as production, consumption and circulation of goods and services, are organized globally either directly or through a network of links between economic agents. It is networked, because in the new historical conditions, achieving a certain level of productivity and the existence of competition is possible only within the global interconnected network» $\gg^{75}$.

Table 1 shows the stages of socio-technological change in society from the agrarian phase to the formation of knowledge economy and network society. It should be noted that each subsequent phase of development of society is characterized by the emergence of new regularities of infrastructure development. A characteristic feature of the post-industrial phase can be considered the global transformation of infrastructure and, as a consequence, the strengthening of the integration of national systems and the development of interdependence of countries.

Thus, theories of post-industrial society make it possible to see that the main source of economic development of countries and factors of global economic progress is information and technologies, and also emphasize the importance of the services sector, which is an indicator of socioeconomic growth. Certainly, the sphere of material production does not lose its importance, but the general tendencies of sectoral shifts in the global economy are a decline in the share of raw materials and agriculture, capital intensive industries, rapid growth of the service sector.

\footnotetext{
${ }^{73}$ Kelly K. (1998) New Rules for the New Economy. Ten Radical Strategies for a Connected World. N.Y.: Penguin Books

Castells M. (2009) Communication Power. Oxford: Oxford University Press ${ }^{75}$ Ibid.

Castells M. (2010) The Information Age: Economy Society and Culture. 2nd Edition. Oxford: Blackwel.
} 


\section{Table 1 Socio-Technological And Infrastructural Parameters Of Formation Of The Facts Of Society Development ${ }^{76}$}

\begin{tabular}{|l|l|l|}
\hline $\begin{array}{c}\text { Phases } \\
\text { of development } \\
\text { of society }\end{array}$ & Socio-technological parameters & \multicolumn{1}{|c|}{ Infrastructure parameters } \\
\hline Agrarian phase & $\begin{array}{l}\text { Feudal society; local agricultural } \\
\text { technologies }\end{array}$ & $\begin{array}{l}\text { Application of natural transport } \\
\text { ways }\end{array}$ \\
\hline Industrial phase & $\begin{array}{l}\text { Urbanization; mass production } \\
\text { technologies }\end{array}$ & $\begin{array}{l}\text { Systematic development of the main } \\
\text { transport infrastructure, able to meet } \\
\text { the needs of urbanized industrial } \\
\text { sites }\end{array}$ \\
\hline $\begin{array}{l}\text { Information } \\
\text { society }\end{array}$ & $\begin{array}{l}\text { Information Economy, } \\
\text { regionalization; megacities; } \\
\text { information technologies }\end{array}$ & $\begin{array}{l}\text { Combination of electronic and } \\
\text { physical transport; the infrastructure } \\
\text { is becoming globalized and } \\
\text { networking; the growth of the role } \\
\text { of aviation transportation }\end{array}$ \\
\hline $\begin{array}{l}\text { Knowledge } \\
\text { society }\end{array}$ & $\begin{array}{l}\text { Global Informational Economy, } \\
\text { regionalization; megacities; } \\
\text { information technologies is the } \\
\text { factor of production and } \\
\text { infrastructure as it is }\end{array}$ & $\begin{array}{l}\text { The organization of traffic flows and } \\
\text { logistics services is based on } \\
\text { information and communication } \\
\text { technologies }\end{array}$ \\
\hline Network society & $\begin{array}{l}\text { Global system (network); } \\
\text { regional polarization; public } \\
\text { technologies }\end{array}$ & $\begin{array}{l}\text { Infrastructure is a global system, a } \\
\text { network that penetrates all levels; } \\
\text { the principles of transportation have } \\
\text { been changed - a transparent mode } \\
\text { of operation that combines } \\
\text { technologies and services }\end{array}$ \\
\hline
\end{tabular}

\section{Structural shifts in the world market of services}

The concept of a post-industrial society was confirmed in practice. The modern stage of development of human civilization is characterized by accelerated development and diversification of the sphere of services practically all over the world. According to the World Bank ${ }^{77}$, in 2016, $69 \%$ of value added was created in the services sector, in industry $27 \%$, in the agrarian sector - only 4\% (Fig. 1). Since 1995, the value added of services has increased by $11 \%$ due to the growth of physical volumes of trade in the World Economics, the development of transport and other services.

\footnotetext{
${ }^{76}$ Developed by authors based on data Castells M. (2010) The Information Age: Economy Society and Culture. 2nd Edition. Oxford: Blackwel; Toffler A. (1980) The Third Wave. New York: Bantam; World Bank (2018) World Development Indicators. [online] Available at: https://data.worldbank.org/data-catalog/world-developmentindicators

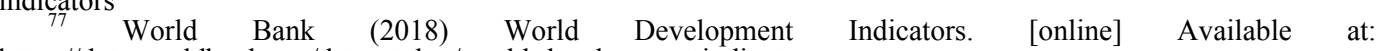
https://data.worldbank.org/datacatalog/world-development-indicators
} 


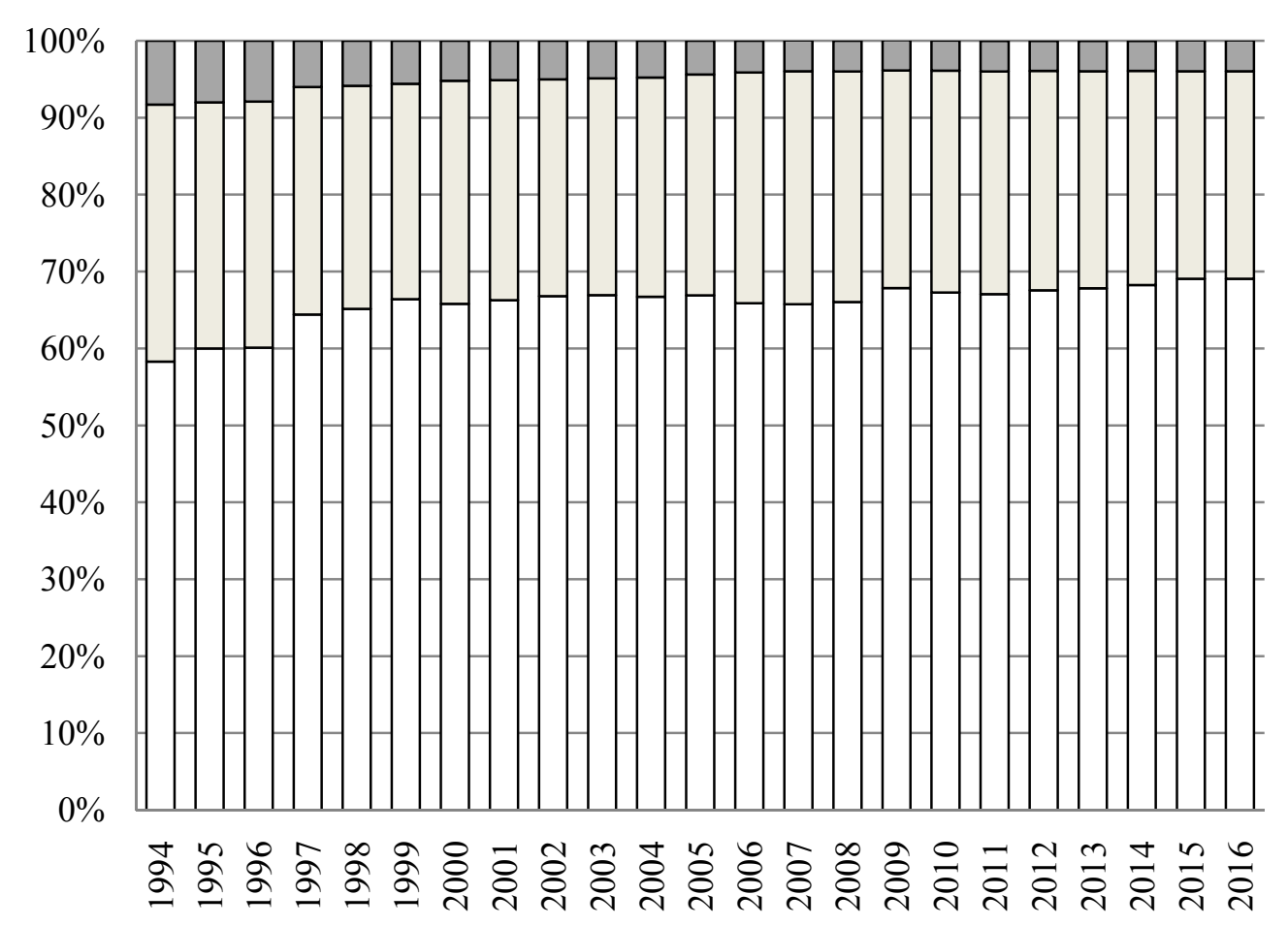

$\square$ Agrarian sector $\square$ Industry $\quad \square$ Sector of services

Fig. 1. Added value of the sectors of the Economics in the structure of GDP, $\%:{ }^{78}$

In 2016, foreign trade turnover in the world reached $\$ 9501.8$ bln US dollars, of which 4807.7 bln US dollars - exports $(23.2 \%$ of exports of goods and services) and \$ 4694.1 bln US dollars - import ${ }^{79}$.

Analyzing statistical data of the World Trade Organization ${ }^{80}$, it can be seen that since 1976, world exports of goods increased by 16.5 times, while world service exports grew by 25.4 times, imports - by 21.4 times. During the mentioned period, the average annual rate of growth of exports in the services sector was 5.4\% (for comparison - the average annual growth rate of exports of goods was $3.7 \%$ ).

\footnotetext{
${ }^{78}$ Developed by the authors as per data World Bank (2018) World Development Indicators. [online] Available at: httpps://data.worldbank.org/datacatalog/world-development-indicators

${ }_{79}$ Ibid.

${ }^{80}$ WTO (2017) World trade statistical review 2017. [online] Available at: www.wto.org/statistics.
} 
Today, the level of development of services is a determining factor in the global competitiveness of national economies ${ }^{81}$. Thus, according to World Bank data, the leading place in the world market of services is occupied by high-income countries per capita, which in 2016 accounted for $78.8 \%$ of world exports of services. The share of world exports of services in countries with higher incomes above the average was $13.4 \%$, countries with lower incomes than the average $-7.2 \%$, and low incomes $-0.6 \%$, respectively ${ }^{82}$.

If we consider the world market of services in terms of its geographic structure, it should be noted that although the lion's share belongs to the EU countries (42.5\% of world exports and $38.5 \%$ of imports of services), however, the growth rate of exports of services of EU countries in 2016 compared to 2008 were only 9\%. The US accounted for $15.2 \%$ of exports and $10.3 \%$ of world imports of services, and growth rates in 2016 compared to 2008 amounted to $42.6 \%$ and $26.8 \%$ respectively. Middle East countries (the growth rate of exports of services in 2016 compared with $2008+81 \%)$, Asia $(+44 \%)^{83}$ are involved in the international trade of services by dynamic rates. Consequently, at the present stage of the post-industrial phase of the development of society, the intensification of international trade and regional diversification become signs of global regularities of development of the world market of services ${ }^{84}$.

In the structure of world trade in services over the past decade there is a tendency to reduce the share of transport services (Figure 2), which is associated with the rationalization of transportation and placement of production in the consumption countries, and with the emergence of new types of services in the world market ${ }^{85}$. A trend is considered to be an increase in the share of tourist services.

This is due to a combination of factors of socioeconomic nature, such as improving the quality of life, improving the transport network, weakening of customs, currency restrictions and border formalities, the absence of global military conflicts, information globalization ${ }^{86}$. The dynamic development of international trade in information services

${ }^{81}$ Sidenko S.V. (2017) Svitovyi rynok posluh v umovakh hlobalnykh transformatsii. Stratehiia rozvytku Ukrainy, 2, s. 7-13 [In Ukranian].

World Bank (2018) World Development Indicators. [online] Available at: https://data.worldbank.org/datacatalog/world-development-indicator

${ }^{83}$ WTO (2017) World trade statistical review 2017. [online] Available at: www.wto.org/statistics

${ }^{84}$ Sidenko S. (2018) The role of human capital in the development of production and trade in high-tech goods and services. Innovative Trends in World Trade Development, p. 425.

${ }^{85}$ Tsyhankova T.M. (2018) Upravlinnia mizhnarodnoiu konkurentospromozhnistiu krain: ekolohichnyi aspekt. Ekonomichnyi prostir, 133, s. 40-56 [In Ukranian].

Lozhachevska O.M. (2017) Analiz svitovoho rynku biznes-aviatsii v umovakh hlobalnoi konkurentsii. Naukovyi visnyk Khersonskoho derzhavnoho universytetu, 24, 1, s. 26-30 [In Ukranian].; Lozhachevska O. (2016) Transforming the world services market. Asian Journal of Scientific and Educational Research, 1(19), p. 124-135. 
shows the significant impact of scientific and technological progress on the formation of the world market of services.

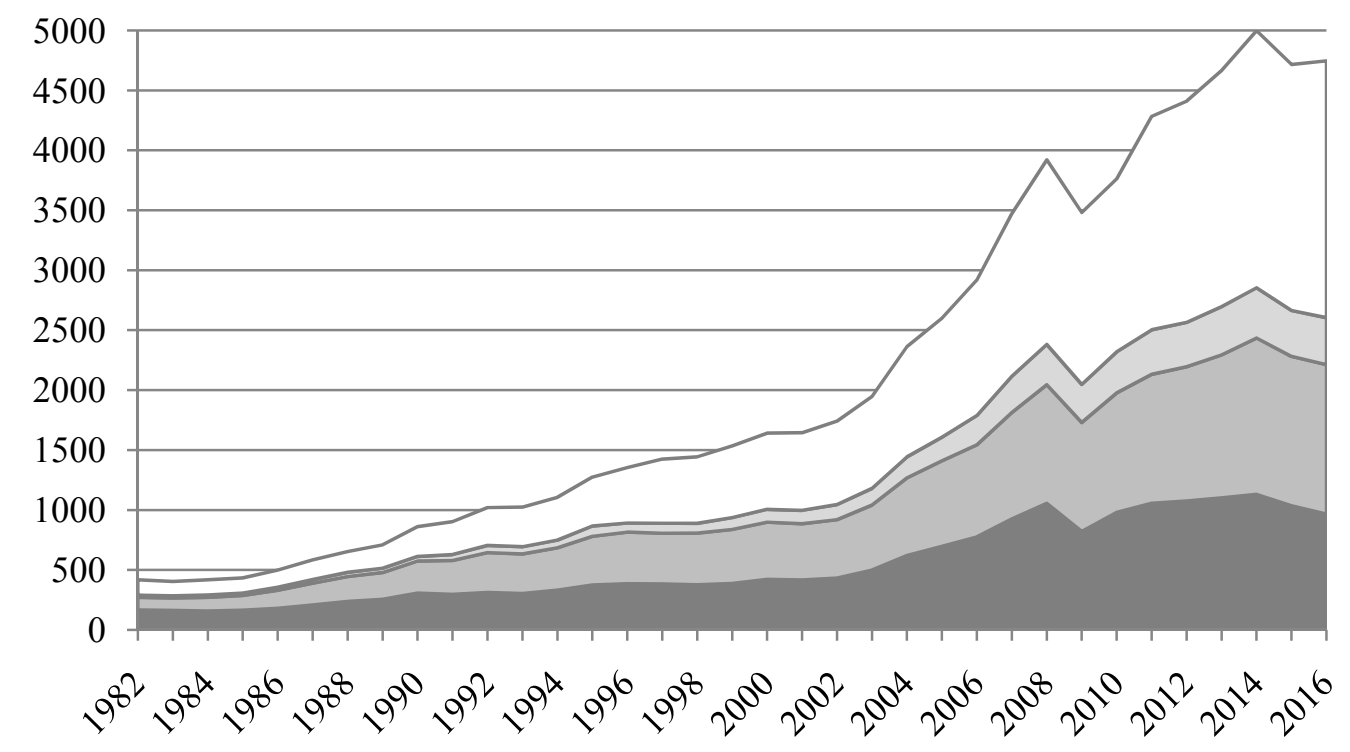

$\square$ Computer, information, communication and other commercial services

$\square$ Insurance and financial services

$\square$ Tourism

Transport

Fig. 2. Structural shifts in the world market of commercial services, bln US dollars

(average performance of export and import of commercial services) ${ }^{87}$

Thus, despite a slight reduction in the structure of international trade in services, transport services traditionally, along with tourism, continue to occupy a leading position. The volume of transport services increases with each passing year in all major modes of transport, which emphasizes the importance of infrastructure services. Trade in transport services covers virtually all countries and is one of the catalysts for globalization of the World Economics.

\footnotetext{
${ }^{87}$ Developed by the authors as per data World Bank (2018) World Development Indicators. [online] Available at: https://data.worldbank.org/datacatalog/world-development-indicators
} 


\section{Global trends in the formation of the global aviation transportation market}

If we consider directly the world market of aviation transport services, then it should be emphasized the global regularities of increase in the volume of aviation transportation. Over the past 70 years since the signing of the Chicago Convention on International Civil Aviation, without taking into account several short-term periods, the volume of passenger, cargo, baggage and mail traffic, frequency of aircraft flights has steadily increased (Fig. 3).

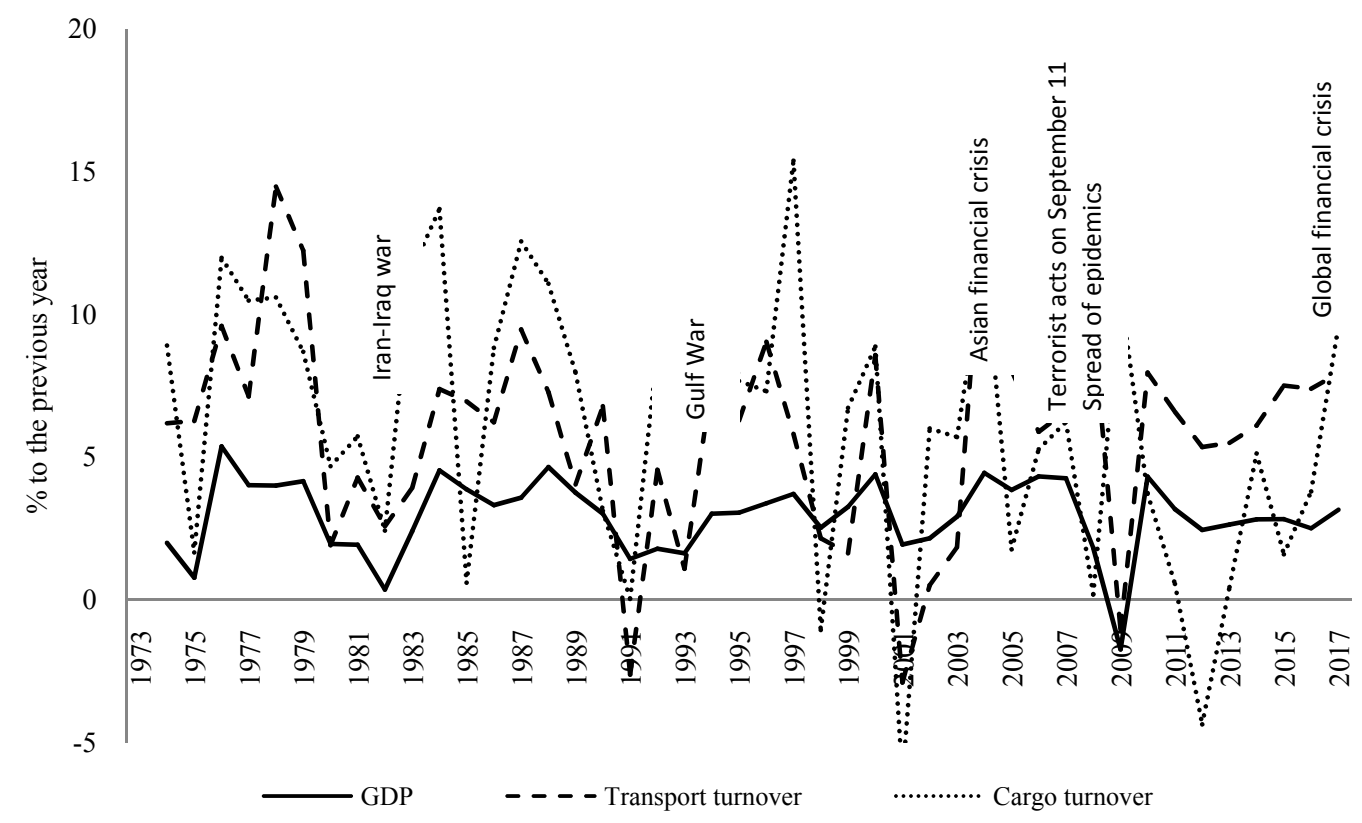

Fig. 3. Annual growth of world GDP

and volumes of aviation transportation ${ }^{88}$

According to the estimates of the International Civil Aviation Organization, in 20174.071 billion passengers, 56.1 million tons of cargo were transported by the airports of the world. Analyzing the performance of world aviation ${ }^{89}$, it becomes apparent that in 2017, compared with 1973, the volume of passenger-kilometers performed

${ }^{88}$ Developed by the authors as per data ICAO (2018) Annual Reports of the Council. [online] Available at:
https://www.icao.int/abouticao/Pages/annual-reports.aspx; World Bank (2018) World Development Indicators.
[online] Available at: https://data.worldbank.org/datacatalog/world-development-indicators
$\begin{array}{lllll}89 & \text { ICAO (2018) Annual Reports of the Council. [online] Available } & \text { at: }\end{array}$
https://www.icao.int/abouticao/Pages/annual-reports.aspx 
increased by 12 times, ton-kilometers by 14 times, while world GDP grew by 17 times. This is a reflection of positive economic changes, despite the slow economic growth in some regions of the world.

Significant disparities are observed in the geographic structure of the global aviation transportation market. Thus, in the field of international air services, the airports of the Asia-Pacific region (APR) are in second place after Europe (Fig. 4) by the number of passengers sent / received.

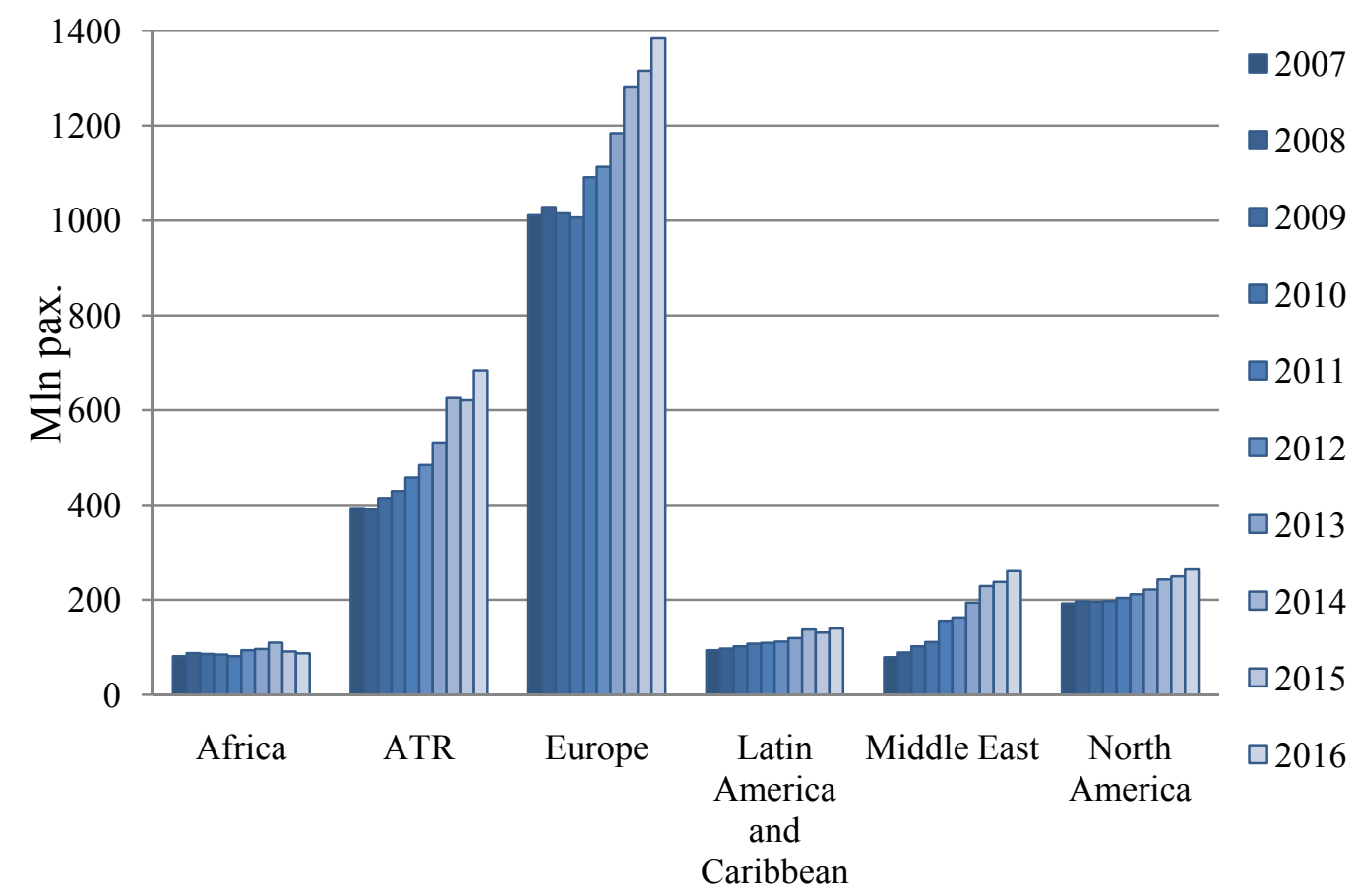

Fig.4 Geographical structure of the world market of aviation transportation by volumes of passengers sent / accepted by airports (in international connections) ${ }^{90}$

The liberalization and globalization of the world's industry have had a significant impact on international trade and the expansion of international air freight markets. The industry is becoming more global in nature; the need for transportation of finished and intermediate

\footnotetext{
${ }^{90}$ Developed by the authors as per data ACI (2018) Airport Statistics and Data Centre. [online] Available at: http://www.aci.aero/Data-Centre; ICAO (2018) Annual Reports of the Council. [online] Available at: https://www.icao.int/abouticao/Pages/annual-reports.aspx
} 
products at huge distances in a relatively short period of time raises the demand for air freight by comparison with other modes of transport ${ }^{91}$. As can be seen from Fig. 5, APR airports dominate the global air freight market. It should be added that the total cost of goods transported by air constitutes $35 \%$ of world trade.

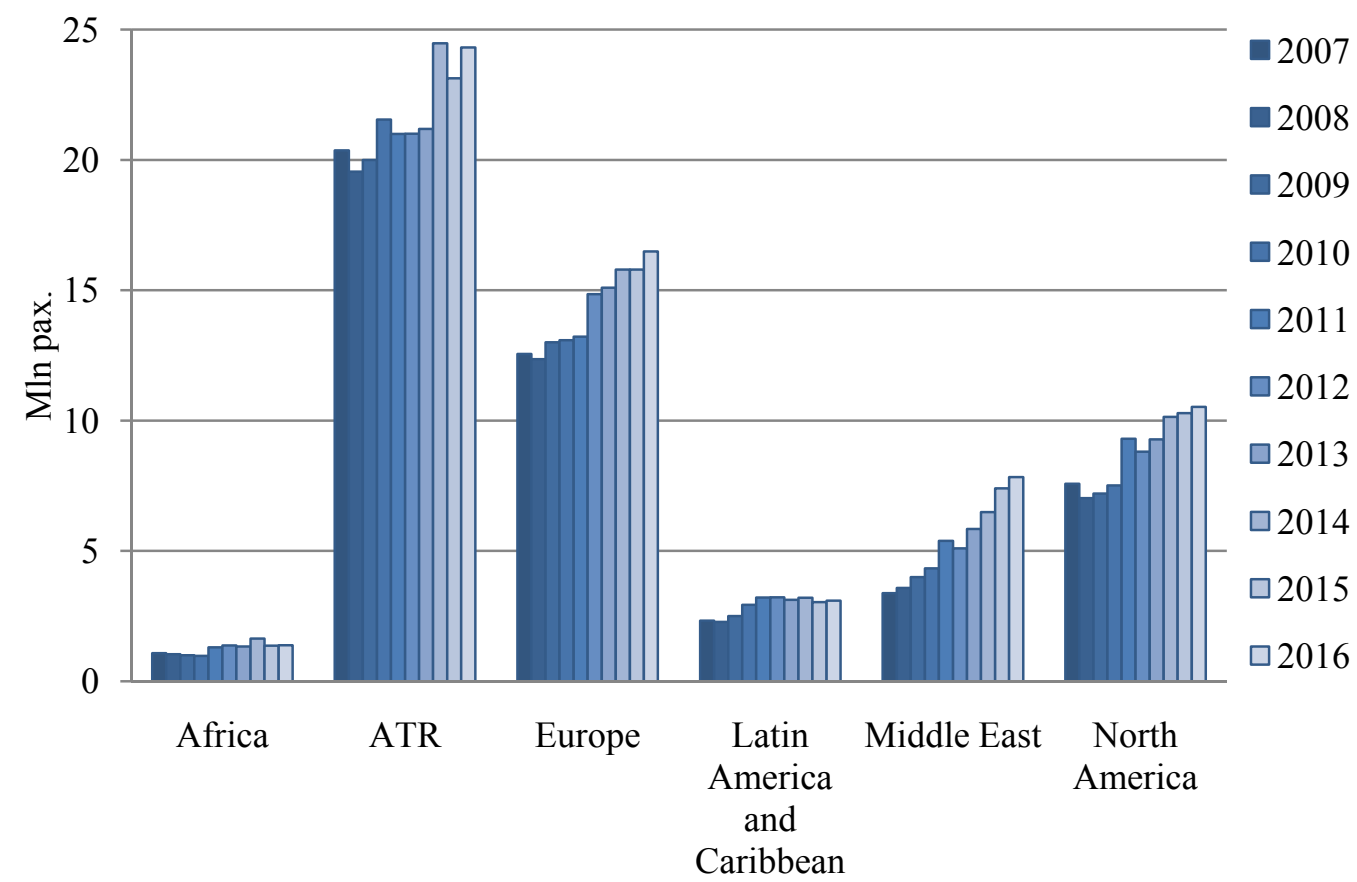

Fig. 5. Geographical structure of the world market of aviation transportation bv volumes of cargo loaded / unloaded by airports (in international connections) ${ }^{92}$

In 2017, as in the previous period, the share of international air passenger transportation was $41 \%$, cargo $-66 \%$ in the total volume of aviation transportation. However, in some regions, these indicators had significant volatility. In particular, the share of international aviation transportation of airports in Europe in 2016 was by the number of sent /

\footnotetext{
${ }^{91}$ Sydorenko K.V. (2018) Upravlinnia mizhnarodnoiu konkurentospromozhnistiu vyrobnychoi infrastruktury aeroportiv v dosiahnenni tsilei stiikoho rozvytku: teoretyko-metodychnyi pidkhid. U: Stiikyi rozvytok pidpryiemstv $u$ mizhnarodnomu ekonomichnomu prostori, za red. O. Arefievoi. K.: Vydavnytstvo, s. 50-64 [In Ukranian].

Developed by the authors as per data ACI (2018) Airport Statistics and Data Centre. [online] Available at: http://www.aci.aero/Data-Centre; ICAO (2018) Annual Reports of the Council. [online] Available at: https:/www.icao.int/abouticao/Pages/annual-reports.aspx
} 
received passengers $-73 \%$, by the number of loaded / unloaded cargo $89 \%$, Middle East airports $-87 \%$ and $98 \%$, respectively, Africa $61 \%$ and 91 $\%$. The high share $(70 \%)$ in international aviation transportation of cargo belongs to APR airports, although the share of international passenger traffic is only $38 \%$. At the same time, the departure and arrival of passengers and cargo on domestic airlines dominated at the North American market, and in the first place the United States. Only 15\% of sent and / or accepted passengers and 36\% of loaded / unloaded cargo accounted for international air connections in this region ${ }^{93}$.

Global aviation markets remain dynamic in terms of economic uncertainty and geopolitical risks, but the growing internationalization of production has an unequivocal impact on the revitalization of airports. Reducing restrictions on the movement of goods and people stimulates the process of further integration of countries.

Thus, with the development of society - from the agrarian phase to the stage of the network society, the infrastructure was undergoing significant transformational transformations, and with the development of the global air transport market, the following regularities of its development, such as the increase in the volume of air travel of passengers and goods, regional diversification, the growth of interdependence of national economies in world economy.

\section{Conclusion}

1. The separation and author's systematization of the sociotechnological and infrastructural parameters of forming the stages of society's development shows that during each phase (agrarian, industrial, post-industrial) infrastructure undergone revolutionary changes caused by technological innovations, as well as due to a shift in the structure of production, and in modern conditions becomes global, creating a global communications network and strengthening the interdependence of national economies.

2. Concepts of the post-industrial society have been confirmed in practice; the sphere of material production does not lose its importance, but the general tendencies of structural changes in the World Economics are the decline in the share of raw materials and agriculture, capital intensive industries, the rapid growth of the service sector (computer, information, communication, transport services, tourism, etc.), their regional diversification.

3. A characteristic feature of post-industrialism is the increase in the volume of international aviation transportation of passengers and cargo,

\footnotetext{
${ }^{93}$ ACI (2018) Airport Statistics and Data Centre. [online] Available at: http://www.aci.aero/Data-Centre
} 
regional diversification and the growth of the interdependence of national economies, since improving air transport infrastructure and reducing transportation costs under the influence of scientific and technological progress can intensify trade and economic cooperation between geographically distant regions, leads to a reduction in the cost of spatial organization of international economic systems.

\section{References}

1. ACI (2018) Airport Statistics and Data Centre. [online] Available at: http://www.aci.aero/Data-Centre.

2. Balbi G., Moraglio M. (2016) A Proposal to hybridise communication and mobility research agendas. In: S. Fari, M. Moraglio, eds. Peripheral flows: $A$ Historical Perspective on Mobilities between Cores and Fringes. Newcastle: Cambridge Scholars Publishing, p. 10-27.

3. Bell D. (1973) The coming of postindustrial society: A venture of social forecasting. N.Y.: Basic Books.

4. Bell D. (1976) The Cultural Contradictions of Capitalism. NY.: Basic Books.

5. Bell D. (2004) Gryadushchee postindustrialnoe obshchestvo. Opyt sotsialnogo prognozirovaniya. Perevod s angl. V. Inozemtsev. M.: Academia [In Russian].

6. Belobaba P., Odoni A., Barnhart C. (2009) The Global Airline Industry. West Sussex: Wiley.

7. Burmich O.S., Lukianenko O.D., Panchenko Ye.H., Chuzhykov V.I. (2013) Tekhnolohichna modernizatsiia v Yevropeiskii ekonomitsi. K.:KNEU [In Ukranian].

8. Butko M.P., Sydorenko I.V. (2013) Evoliutsiini pohliady na modernizatsiiu riznykh iierarkhichnykh rivniv vyrobnychoi infrastruktury. Ekonomist, 3, s. 11-14 [In Ukranian].

9. Button K., Vega H. (2012) Globalization and transport (The globalization of the world economy series. Cheltenham: Edward Elgar Pub.

10. Canning D., Pedroni P. (2004) The effect of infrastructure on long run economic growth. M.: Harvard University.

11. Castells M. (2000) The Information Age: Economy Society and Culture. Volume I: The Rise of the Network Society. Second Edition. Oxford: Blackwel.

12. Castells M. (2009) Communication Power. Oxford: Oxford University Press.

13. Castells M. (2010) The Information Age: Economy Society and Culture. 2nd Edition. Oxford: Blackwel.

14. Chukhno A.A. (2003) Postindustrialna ekonomika: teoriia, praktyka ta yikh znachennia dlia Ukrainy. K.: Lohos [In Ukranian].

15. Chuzhykov V.I. (2010) Aviatsiini aliansy v hlobalnii konkurentnii modeli KhKhI stolittia. Visnyk Derzhavnoi komisii z tsinnykh paperiv ta fondovoho rynku, 3-4, s. 9-16 [In Ukranian].

16. Clark C. (1940) The Conditions of Economic Progress. London: Macmillan.

17. Crafts N. (2009) Transport infrastructure investment: implications for growth and productivity. Oxford review of economic policy, 25 (3), p. 27-43. DOI: $10.1093 /$ oxrep /grp021.

18. Crockat M. (2000) Airport infrastructure and regional development: a case for resurrecting the growth pole concept. Winnipeg: University of Manitoba. 
19. Druker P. (1990) Postkapitalisticheskoe obshchestvo. M.: Academia [In Russian].

20. European Commission (2016b) The implementation of the 2011 White Paper on Transport «Roadmap to a Single European Transport Area - towards a competitive and resource-efficient transport system» five years after its publication: achievements and challenges. Brussels: European Commission.

21. Filipenko A.S. (2016) Ekonomichnyi svit: epistemolohiia. Ekonomichna teoriia, 1, s. 17-25 [In Ukranian].

22. Fisher A. (1939) Production, primary, secondary and tertiary. Economic Record, 15.1, pp. 24-38. DOI: 10.1111/j.1475-4932.1939.tb01015.x

23. Gelbreyt Dzh. K. (1969) Novoe industrialnoe obshchestvo. Per. s angl. M.: Progress [In Russian].

24. Halchynskyi A.S., Heiets V.M., Kinakh A.K., Semynozhenko V.P. (2004) Innovatsiina stratehiia ukrainskykh reform. K.: Znannia Ukrainy [In Ukranian].

25. Heiets V.M. (2014) Modernizatsiia v systemi «suspilstvo - derzhava ekonomika». Zhurnal yevropeiskoi ekonomiky, 13, 3, s. 221-235 [In Ukranian].

26. Hensher D. (2010) Transport Economics and Markets. Economic Papers: A journal of applied economics and policy, 20, 2. DOI: $10.1111 / \mathrm{j} .1759-$ 3441.2001.tb00280.x.

27. Hrychkoiedova M.V. (2010) Suchasni tendentsii rozvytku biznes-aviatsii u sviti. Problemy pidvyshchennia efektyonosti infrastruktury, 28, s. 247 [In Ukranian].

28. Hryhorak M.Iu., Savchenko L.V. (2017) Lohistychni kontseptsii rozoytku aeroportiv. K.: Lohos [In Ukranian].

29. Hussain M. (2010) Investment in Air Transport Infrastructure. Washington: World Bank.

30. ICAO (2018) Annual Reports of the Council. [online] Available at: https: / / www.icao.int/about-icao/Pages/annual-reports.aspx.

31. Itani N., O'Connell J., Mason K. (2014) A macro-environment approach to civil aviation strategic planning. Transport Policy, 33, p. 125-135. DOI: $10.1016 /$ j.tranpol.2014.02.024

32. Ivanova N.V. (2015) Metodolohichni aspekty formuvannia peredumov modernizatsii vyrobnychoi infrastruktury. Hlobalni ta natsionalni problemy ekonomiky, 6, s. 543-549 [In Ukranian].

33. Katz R. (1988) The Information Society: An International Perspective. N.Y.: Praeger. Lindberg.

34. Kelly K. (1998) New Rules for the New Economy. Ten Radical Strategies for a Connected World. N.Y.: Penguin Books.

35. Khakhliuk A.M. (2007) Infrastrukturni haluzi u svitovomu hospodarstvi. U: A.S.Filipenko (red.) Svitova ekonomika. K.: Lybid, s. 314-334 [In Ukranian].

36. Lozhachevska O.M. (2017) Analiz svitovoho rynku biznes-aviatsii v umovakh hlobalnoi konkurentsii. Naukovyi visnyk Khersonskoho derzhavnoho universytetu, 24, 1, s. 26-30 [In Ukranian].

37. Lozhachevska O.M., Sydorenko K.V. (2017) Mistse vyrobnychoi infrastruktury mizhnarodnykh aeroportiv u systemi zabezpechennia hlobalnoi konkurentospromozhnosti. Ekonomichnyi prostir, 125, s. 17-26 [In Ukranian].

38. Lozhachevska O. (2016) Transforming the world services market. Asian Journal of Scientific and Educational Research, 1(19), p. 124-135. 
39. Macario R., Voorde E. (2010) Critical issues in air transport economics and business. N.Y.: Routledge.

40. Marintseva K. (2013) Analysis of air transport network of Ukraine. Управління проектами, системний аналіз $і$ логістика, 12, с. 97-109.

41. Masuda Y. (1981) The information society as post-industrial society. Washington, D.C.: World Future Society.

42. Novytskyi V.Ie. (2003) Mizhnarodna ekonomichna diialnist Ukrainy. K.: KNEU [In Ukranian].

43. Orlovska Yu.V., Chala V.S. (2013) Vplyv hlobalnykh problem rozvytku postindustrialnoi ekonomiky na kreatyvizatsiiu zovnishnoekonomichnoi diialnosti pidpryiemstv. Ekonomichnyi prostir, 78, s. 32-44 [In Ukranian].

44. Pakhomov Yu.N. Cmena tsely razvytyia kak sposob predotvrashchenyia katastrofы v postyndustryalnom obshchestve. Ekonomichnyi Chasopys - XXI, 1-2, s. 3-4 [In Ukranian].

45. Piriashvili B.Z., Chyrkin B.P., Nykyforuk O.I. ta in. (2014) Zasady modernizatsii vyrobnychoi infrastruktury Ukrainy. K.: In-t ekon. ta prohnozuv. NAN Ukrainy [In Ukranian].

46. Polous O.V. (2018) Osoblyvosti funktsionuvannia lohistychnykh system na meha-, makro- ta makrorivni. Ekonomika. Finansy. Pravo, 1/3, s. 20-24 [In Ukranian].

47. Poltoratska O.T. (2012) Koordynatsiia ta vdoskonalennia vzaiemovidnosyn mizh subiektamy aviatsiinoho prostoru. Stratehiia rozvytku Ukrainy, 3, s. 201-207 [In Ukranian].

48. Porat M., Rubin M. (1978) The Information Economy: Development and Measurement. Washington: Scientific Review.

49. Rietveld P., Nijkamp P. (1993) Transport and regional development. European transport economics. Paris: RCMT, p. 130-151.

50. Rostow W. (1960) The stages of economic growth. 3rd ed. N.Y.: Cambridge University Press. DOI: 10.1017/CBO9780511625824.

51. Rybchuk A.V. (2010) Formuvannia hlobalnoi vyrobnychoi infrastruktury svitovoho hospodarstva: avtoref. dys... d-ra ekon. nauk spets. 08.00.02. K.: Kyivskyi natsionalnyi universytet imeni Tarasa Shevchenka [In Ukranian].

52. Sakayya T. (1999) Stoimost, sozdavaemaya znaniyami ili Istoriya budushchego. M.: Academia [In Russian].

53. Saveliev Ye., Kuryliak V. (2018) Ukraina v hlobalnykh protsesakh posylennia intehratsii elektrychnoho transportu $\mathrm{v}$ systemu hromadskykh perevezen. Zhurnal yevropeiskoi ekonomiky, 17, 1, s. 98-109 [In Ukranian].

54.Shevtsova O.I. (2001) Orhanizatsiino-ekonomichnyi mekhanizm upravlinnia promyslovoiu infrastrukturoiu subiektiv hospodariuvannia: avtoref. dys. ... d-ra ekon. nauk spets. 08.06.01. Donetsk: Instytut ekonomiky promyslovosti NAN Ukrainy [In Ukranian].

55. Sidenko S. (2016) Innovation priorities of Ukraine: the aerospace sector. Economics\&Education International Scientific Journal, №2, p. 14-18.

56. Sidenko S. (2018) The role of human capital in the development of production and trade in high-tech goods and services. Innovative Trends in World Trade Development, p. 425.

57.Sidenko S.V. (2014) Problemy innovatsiinoho rozvytku v umovakh hlobalizatsii. Stratehiia rozvytku Ukrainy (ekonomika, sotsiolohiia, pravo), 2 [In Ukranian]. 
58.Sidenko S.V. (2016) Mizhnarodne spivrobitnytstvo Ukrainy $\mathrm{v}$ sferi innovatsii. Stratehiia rozvytku Ukrainy (ekonomika, sotsiolohiia, pravo), 1, c. 172-176 [In Ukranian].

59. Sidenko S.V. (2017) Svitovyi rynok posluh v umovakh hlobalnykh transformatsii. Stratehiia rozvytku Ukrainy, 2, s. 7-13 [In Ukranian].

60. Stehr N. (1994) Knowledge Societes. London: Sage.

61.Stonier T. (1983) The Wealth of Information. London: Oxford University Press.

62. Sydorenko K.V. (2016) Henezys y hnoseolohyia ynfrastrukturb. Sciences of Europe, 9 (1), r. 55-60 [In Ukranian].

63. Sydorenko K.V. (2018) Upravlinnia mizhnarodnoiu konkurentospromozhnistiu vyrobnychoi infrastruktury aeroportiv $\mathrm{v}$ dosiahnenni tsilei stiikoho rozvytku: teoretyko-metodychnyi pidkhid. U: Stiikyi rozvytok pidpryiemstv u mizhnarodnomu ekonomichnomu prostori, za red. O. Arefievoi. K.: Vydavnytstvo, s. 50-64 [In Ukranian].

64. Toffler A. (1980) The Third Wave. New York: Bantam.

65. Tsyhankova T.M. (2018) Upravlinnia mizhnarodnoiu konkurentospromozhnistiu krain: ekolohichnyi aspekt. Ekonomichnyi prostir, 133, s. 40-56 [In Ukranian].

66. World Bank (2018) World Development Indicators. [online] Available at: https: / / data.worldbank.org / data-catalog/world-development-indicators.

67. Yurchenko S.A. (2006) Infrastruktura mira. Kh.: KhNU [In Russian].

68. Zinchenko V.V. (2013) Postindustrializm, dynamika protsesiv samoorhanizatsii i upravlinska demokratiia $\mathrm{v}$ perspektyvakh transformatsiinykh zmin vektoriv hlobalnoho rozvytku. Hileia: naukovyi visnyk, 70, s. 337-348 [In Ukranian].

The article was received by the editorial board on 01.10 .2018 